\title{
Nesting habits of social wasps (Hymenoptera: Vespidae) in forest fragments associated with anthropic areas in southeastern Brazil
}

\author{
TCT OLIVEIRA 1 , MM SOUZA², EP PIRES ${ }^{3,4}$ \\ 1- Departamento de Biologia, Universidade Federal de Lavras, Minas Gerais, Brazil \\ 2 - Instituto Federal de Educação, Ciência e Tecnologia de Minas Gerais, Inconfidentes-MG, Brazil \\ 3 - Departamento de Entomologia, Universidade Federal de Lavras, Minas Gerais, Brazil
}

\section{Article History \\ Edited by \\ Gilberto M. M. Santos, UEFS, Brazil \\ Received 19 May 2016 \\ Initial acceptance 07 October 2016 \\ Final acceptance 13 February 2017 \\ Publication date 29 May 2017}

\section{Keywords}

Hymenoptera, colony, nesting substrate, synanthropism.

\section{Corresponding author \\ Epifânio Porfiro Pires \\ Departamento de Entomologia \\ Universidade Federal de Lavras - UFLA \\ CEP 37200-000, Lavras, MG, Brasil \\ E-Mail: epifaniopires@yahoo.com.br}

\begin{abstract}
Social wasp communities and nesting habits were evaluated in forest environments associated with areas of human disturbance from March to September 2015. Three hundred forty-seven (347) colonies belonging to eighteen (18) species distributed in six genera were recorded. The species with the highest number of colonies were Mischocyttarus cassununga (R. Von Ilhering, 1903) (194 colonies), Mischocyttarus cerberus Richards, 1940 (50 colonies) and Polybia paulista (H. von Ihering, 1896) (23 colonies). Other species colony numbers ranged from one to eighteen.
\end{abstract}

\section{Introduction}

Social wasps belong to the subfamily Polistinae (Hymenoptera: Vespidae) and comprise more than 950 described species; they are most diverse in the Neotropical region (Pickett \& Carpenter, 2010). Social wasps interact with the various fauna and flora. Some species acting as floral visitors, constituting a significant portion of the foraging guild (Heithaus, 1979; Aguiar \& Santos, 2007; Clemente et al., 2013); they are also predaceous, impacting population dynamics in various prey taxa (Richter, 2000; Souza \& Zanuncio, 2012).

The survival of social wasps depends both on successful colony foundation and strong foraging ability (Dejean et al., 1998; Richter, 2000; Oliveira et al., 2010). These insects can establish nests at various sites in urban or natural environments, and the nesting substrates used are extremely diverse, including the abaxial or adaxial surface of leaves, plant stems, abandoned termite mounds, rocks, and human-made structures (Lima et al., 2000; Alvarenga et al., 2010; López et al., 2012; Souza et al., 2014).

Social wasps colonies can be classified as stelocyttarus, gymnodomous, astelocyttarus, or phragmocyttarus (Richards \& Richards, 1951; Richards, 1978; Carpenter \& Marques, 2001). Stelocyttarus nests are formed by one or more combs attached to the substrate by a peduncle, which may or may not contain a protective involucrum. Gymnodomous nests have no involucrum (characteristic of Mischocyttarus spp. Saussure, 1853, Polistes spp. Latreille, 1802, Agelaia spp Lepeletier, 1836 and Apoica spp. Lepeletier 1836), while calyptodome nests have involucrum (Pseudopolybia spp. Saussure, 1863 and Parachartergus spp. R. von Ihering 1904). Astelocyttarus nests present a single comb with protective involucrum and cells built directly on the substrate (Synoeca spp. Saussure, 1852 and Metapolybia spp. Ducke, 1905). In phragmocyttarus- 
type nests, the initial comb is broadly attached to the protective casing and the subsequent combs are constructed in contact with the sides of the previous combs (Polybia spp. Lepeletier, 1836 and Brachygastra spp. Perty, 1833).

Colony foundation can occur via swarming or independently (Jeanne, 1991; Wenzel, 1998; Carpenter \& Marques, 2001). Swarm founding consists of one or more queens and several workers leaving the original colony to seek a suitable place to build the new colony. For independentfounding species, one or more queens (reproductive females) build a nest, oviposit, and feed larvae (Jeanne, 1991; Wenzel, 1998; Carpenter \& Marques, 2001).

Several studies have pointed out that some social wasp species prefer nesting in human-made structures. These sites provide protection from weather, and reduce the threat of predation and competition for nesting substrates (Marques \& Carvalho, 1993; Lima et al., 2000). In contrast, species that nest only in natural environments prefer specific features and environmental conditions (Dejean et al., 1998; Souza et al., 2010; Souza et al., 2014).

Studies of social wasps nesting habits in urban sites surrounded by natural vegetation are still scarce. The claim that the social wasps prefer urban environments may be misleading, as association with urban areas could be due to invasion and subsequent reduction of natural areas. Studies on the nesting behavior of these insects in the associated environments may provide important information on the ecological characteristics of organisms and their interactions with the environment (Dejean et al., 1998; Souza et al., 2010; Souza et al., 2014).

In this study we characterize the social wasp fauna and describe the various nesting substrates in forest fragments associated with anthropogenically impacted areas in southeastern Brazil.

\section{Material and Methods}

\section{Study area}

The study was conducted in Atlantic forest fragments with high human disturbance. The forest area has an elevation of $864 \mathrm{~m}$ and contains 215.62 hectares, and is located in IFSULDEMINAS (22 19 ' $2^{\prime}$ ' S, $46^{\circ} 19^{\prime} 42^{\prime}$ ' $)$ in Inconfidentes Campus, Minas Gerais. Regional vegetation landscape is characterized by fragments of Semideciduous Montane Seasonal Forest and Riparian Forest, which are undergoing constant human interventions in association with economic cycles for agriculture and livestock production. The climate is classified as $\mathrm{Cwb}$ (mesothermal with well-defined seasons), with an annual average temperature ranging from 13.1 to $23.7^{\circ} \mathrm{C}$ and average annual rainfall of 1,800 $\mathrm{mm}$ (Sarmento et al., 2013).

\section{Methodology}

The survey was conducted from March to September of 2015, with a total sampling effort of 30 days. Nest searching and specimen collection was carried out by means of active search (Souza \& Prezoto, 2006). Buildings on the campus and in forest areas were inspected. When colonies were discovered we recorded the species, the number of colonies, and types of substrates used. The types of substrates used by different species were grouped into the following categories: man-made structures (windows, metals, aluminum structures, concrete masonry units, poles, pipes, water tanks, wooden slats, and roofs), barranco, and plant substrate (all plants in which nests were found).

Specimens were collected species confirmation. Species identities were determined using a taxonomic keys by Richards (1978), Carpenter and Marques (2001) and Carpenter (2004). Species identities were confirmed by professor Dr. Orlando Tobias Silveira of the Pará Emilio Goeldi Museum in Belém, Pará.

\section{Results and Discussion}

A total of 347 social wasps colonies were found, belonging to 18 species distributed among six genera. Of this total, 73\% belonged to the genus Mischocyttarus, $15 \%$ to Polybia, $8 \%$ to Polistes, $2 \%$ to Synoeca and $1 \%$ each to Parachartergus and Brachygastra (Table 1). The greatest proportion of colonies ( $87 \%$ ) occurred in man-made structures (Table 1), however diversity and species richness was higher in plant substrates (Table 1). The species with the greatest numbers of colonies were Mischocyttarus cassununga (R. von Ihering, 1903) (194 colonies), Mischocyttarus cerberus Richards, 1940 (50 colonies) and Polybia paulista (H. von Ihering, 1896) (23 colonies). Other species had between one and 18 colonies each (Table 1).

Many studies conducted in urban environments have revealed high diversity in social wasps, with higher incidence of species in the genera Mischocyttarus, Polybia, Polistes and Protopolybia (Lima et al., 2000; Alvarenga et al., 2010; López et al., 2012).

Colonies of M. cassununga, Polistes simillimus (Zikán, 1951), Polistes versicolor (Olivier, 1791) and Mischocyttarus drewseni (Saussure, 1857) occurred only in man-made structures, suggesting synanthropism in these species (Jeanne, 1972; Raposo-Filho \& Rodrigues, 1984; Marques \& Carvalho, 1993; Lima et al., 2000; Torres et al., 2011; Castro et al., 2014).

Mischocyttarus rotundicollis (Cameron, 1912), Polybia scutellaris (White, 1841), P. paulista, M. cerberus, and Polybia fastidiosuscula (Saussure, 1854) were recorded in both natural and man-made substrates. In contrast, Polybia platycephala slyventris (Richards, 1978), Synoeca cyanea (Fabricius, 1775), Polybia jurinei (Saussure, 1854), Parachartegus fraternus (Griboldo, 1892), Polybia occidentalis (Olivier, 19711), Polybia sericea (Olivier, 1971), Polybia chrysothorax (Lichtenstein, 1796), Brachygastra lecheguana (Latreille, 1824) and Polybia minarum (Ducke, 1906) were found only in plant substrates (Table 1).

Based on the results, the availability of specific substrates for nesting seems to be a limiting factor for the species occurrence in certain environments. This is especially true 
Table 1. List of social wasp species and number of colonies recorded in urban fragments in the municipality of Inconfidentes, Minas Gerais, Brazil, in the period from March to September of 2015.

\begin{tabular}{|c|c|c|c|c|}
\hline \multirow[t]{2}{*}{ Species } & \multicolumn{3}{|c|}{ Number of colonies } & \multirow[t]{2}{*}{ Total } \\
\hline & Buildings* & Plant & Barranco & \\
\hline Brachygastra lecheguana (Latreille, 1824) & 0 & 1 & 0 & 1 \\
\hline Mischocyttarus cassununga (R. von Ihering, 1903) & 191 & 3 & 0 & 194 \\
\hline Mischocyttarus cerberus Richards, 1940 & 49 & 1 & 0 & 50 \\
\hline Mischocyttarus drewseni Saussure, 1857 & 3 & 0 & 0 & 3 \\
\hline Mischocyttarus rotundicollis (Cameron, 1912) & 8 & 0 & 1 & 9 \\
\hline Parachartergus fraternus (Griboldo, 1892) & 0 & 1 & 0 & 1 \\
\hline Polistes simillimus (Zikán, 1951) & 18 & 0 & 0 & 18 \\
\hline Polistes versicolor (Olivier,1791) & 10 & 0 & 0 & 10 \\
\hline Polybia chrysothorax (Lichtenstein, 1796) & 0 & 2 & 0 & 2 \\
\hline Polybia fastidiosuscula (Saussure, 1854) & 2 & 1 & 0 & 3 \\
\hline Polybia jurinei (Saussure, 1854) & 0 & 1 & 0 & 1 \\
\hline Polybia minarum (Ducke, 1906) & 0 & 1 & 0 & 1 \\
\hline Polybia occidentalis (Olivier, 19711) & 0 & 9 & 0 & 9 \\
\hline Polybia paulista (H. von Ihering, 1896) & 14 & 9 & 0 & 23 \\
\hline Polybia platycephala sylventris (Richards, 1978) & 0 & 4 & 0 & 4 \\
\hline Polybia scutellaris (White, 1841) & 7 & 2 & 0 & 9 \\
\hline Polybia sericea (Olivier, 1971) & 0 & 1 & 0 & 1 \\
\hline Synoeca cyanea (Fabricius, 1775) & 0 & 8 & 0 & 8 \\
\hline Number of colonies & 302 & 44 & 1 & 347 \\
\hline Richness of species (S') & 9 & 14 & 1 & 18 \\
\hline
\end{tabular}

* Windows, metals, aluminum structures, walls, poles, pipes, cisterns water, wood slat and roof.

for species that construct astelocyttarus-type nests, such as Synoeca and Metapolybia which build a single comb with a protective involucrum with cells attached directly to the substrate (Richards \& Richards, 1951); this partially explains the absence of species in these genera in several studies in urban areas (Dejean et al., 1998; Souza et al., 2010).

The results from this study provide a better understanding of social wasp communities associated with human-modified environments. It is clear that although most species have generalist habits with respect to substrate choice for nest-building, others seem to prefer specific characteristics for colony construction. Areas of vegetation in forest fragments associated with urban environments are vital for the maintenance of social wasp populations, and consequently play a role in maintaining environmental services provided by these insects such as biological control, pollination, and maintenance of trophic webs (Alvarenga et al., 2010). Further studies are needed in these environments that evaluate the potential use for social wasps as indicators of environmental quality, as well as to ensure species conservation, especially for those which require specific features for nesting.

\section{References}

Aguiar, C.M.L. \& Santos, G.M.M. (2007). Compartilhamento de recursos florais por vespas sociais (Hymenoptera: Vespidae) e abelhas (Hymenoptera: Apoidea) em uma área de Caatinga. Neotropical Entomology, 36: 836-842. doi: 10.1590/S1519566X2007000600003

Alvarenga, R.D., De Castro, M.M. Santos-Prezoto, H.H. \& Prezoto, F. (2010). Nesting of social wasps (Hymenoptera, Vespidae) in urban gardens in Southeastern Brazil. Sociobiology, 55: 445-452.

Castro, M.M., Avelar, D.L.G., De Souza, A.R. \& Prezoto, F. (2014). Nesting substrata, colony success and productivity of the wasp Mischocyttarus cassununga. Revista Brasileira de Entomologia, 58: 168-172.

Carpenter, J.M. \& Marques, O.M. (2001). Contribuição ao Estudo dos Vespídeos do Brasil. Salvador, Universidade Federal da Bahia, Departamento de Fitotecnia. Série Publicações Digitais, v. 3, CD.

Carpenter, J.M. (2004). Synonymy of the genus Marimbonda Richards 1978, with Leipomeles Mobius, 1856 (Hymenoptera: Vespidae; Polistinae), and a new key to the genera of paper wasps of the New World. American Museum Novitates, 3465: 1-16.

Clemente, M.A., Lange, D., Dattilo, W., Del-Claro, K. \& Prezoto, F. (2013). Social Wasp-Flower Visiting Guild Interactions in Less Structurally Complex Habitats are More Susceptible to 
Local Extinction. Sociobiology, 60: 337-344. doi: 10,13102/ sociobiology.v60i3.337-344

Dejean, A., Corbara, B. \& Carpenter, J.M. (1998). Nesting site selection by wasps in the Guianese rain forest. Insectes Sociaux, 45: 33-41. doi: 10.1016/j.crvi.2009.01.003

Heithaus, E.R. (1979). Community structure of neotropical flower visiting bees and wasps: diversity and phenology. Ecology, 60: 190-202.

Jeanne, R.L. (1972). Social biology of the neotropical wasp Mischocyttarus drewseni. Bulletin of the Museum of Comparative Zoology, 144: 63-150.

Jeanne, R.L. (1991). The swarm-founding Polistinae. In Ross, K.G. \& R.W.Matthews (Eds.). The social biology of wasps, (pp. 191-231). New York: Cornell University.

Lima, M.A.P., Lima, J.R. \& Prezoto F. (2000). Levantamento dos gêneros, flutuação das colônias e hábitos de nidificação de vespas sociais (Hymenoptera, Vespidae), no campus da UFJF, Juiz de Fora, MG. Revista Brasileira de Zoociências, 2:69-80.

López, Y., Canchila, S., Durán, A. \& Álvarez, D. (2012). Hábitos de nidificación de avispas sociales (Vespidae: Polistinae) en un área urbana del Caribe colombiano. Revista Colombiana de Entomologia, 38: 347-350.

Marques, O.M., Carvalho, C.A.L. \& Costa, J.M. (1993) Levantamento das espécies de vespas sociais (Hymenoptera: Vespidae) no município de Cruz das Almas-estado da Bahia. Insecta, 2: 1-9.

Oliveira, S.A.D.; Castro, M.M. \& Prezoto, F. (2010). Foundation pattern, productivity and colony success of the paper wasp, Polistes versicolor. Journal of Insect Science, 10:10-125. doi: 10.1673/031.010.12501

Pickett, K. M. \& Carpenter, J. M. (2010). Simultaneous Analisys and the Origin of Eusociality in the Vespidae (Insecta: Hymenoptera). Arthropod Systematics and Phylogeny, 68: 3-33.

Raposo-Filho, J.R. \& Rodrigues, V.M. (1984). Habitat e local de nidificação de Mischocyttarus (Monocyttarus) extinctus
Zikán, 1935 (Polistinae-Vespidae). Anais da Sociedade Entomológica do Brasil, 13: 19-28.

Richards, O.W. \& Richards, M.J. (1951). Observations on the social wasps of South America (Hymenoptera, Vespidae). Transactions of the Royal Entomological Society of London, 102: 1-169.

Richards, O.W. (1978). The social wasps of the Americas excluding the Vespinae. London: British Museum (Natural History), $580 \mathrm{p}$

Richter, M.R. (2000). Social wasp (Hymenoptera, Vespidae) foraging behavior. Annual Review of Entomology, 45: 121-150

Sarmento, B.M., Corrêa, B.S., Loures, L. \& De Moura, A.S. (2013). Avaliação do desenvolvimento de mudas nativas de uma área paludosa, no município de Inconfidentes. Revista Agrogeoambiental, 5: 63-82.

Souza, M.M. \& Prezoto, F. (2006). Diversity of social wasps (Hymenoptera: Vespidae) in Semideciduous forest and cerrrado (savanna) regions in Brazil. Sociobiology, 47: 135-147.

Souza, M.M., Louzada, J., Serrão, J.E. \& Zanuncio, J.C. (2010). Social wasps (Hymenoptera: Vespidae) as indicators of conservation degree of riparian forests in Southeast Brazil. Sociobiology, 56: 387-396.

Souza, M.M. \& Zanuncio, J.C. (2012). Marimbondos-Vespas Sociais (Hymenoptera: Vespidae). Viçosa: Editora UFV, 79p.

Souza, M.M., Pires, E.P., Elpino-Campos, A. \& Louzada, J.N.C. (2014). Nesting of social wasps (Hymenoptera: Vespidae) in a riparian forest of Rio das Mortes in southeastern Brazil. Acta Scientiarum-Biological Sciences 36: 189-196. doi: 10.4025/ actascibiolsci.v36i2.21460

Torres, V.O., Montagna, T.S., Fernandes, W.D. \& AntonialliJunior, W.F. (2011). Colony cycle of the social wasp Mischocyttarus consimilis Zikán (Hymenoptera, Vespidae). Revista Brasileira de Entomologia, 55: 247-252.

Wenzel, J.W. (1998). A generic key to the nests of hornets, yellowjackets, and paper wasps worldwide (Vespidae: Vespinae, Polistinae). American Museum Novitates, 3224: 1-39. 